"In Near Ruins: Cultural Theory at the End of the Century"

Nicholas Dirks

CSST Working

Paper \#121

October 1996

CRSO Working

Paper \#548 


\title{
In Near Ruins: Cultural Theory at the End of the Century ${ }^{1}$
}

\author{
Nicholas B. Dirks
}

\begin{abstract}
"The Villa san Girolamo, built to protect inhabitants from the flesh of the devil, had the look of a besieged fortress, the limbs of most of the statues blown off during the first days of shelling. There seemed little demarcation between house and landscape, between damaged building and the bumed and shelled remnants of the earth... Between the kitchen and the destroyed chapel a door led into an oval-shaped library. The space inside seemed safe except for a large hole at portrait level in the far wall, caused by mortar-shell attack on the villa two months earlier. The rest of the room had adapted itself to this wound, accepting the habits of weather, evening stars, the sound of birds. There was a sofa, a piano covered in a grey sheet, the head of a stuffed bear and high walls of books. The shelves nearest the torn wall bowed with the rain, which had doubled the weight of the books. Lightening came into the room too, again and again, falling across the covered piano and carpet."
\end{abstract}

\section{Michael Ondaatje, The English Patient}

The English patient of Ondaatje's novel is a man burnt black beyond recognition, beyond identity. Cared for by a shell-shocked Canadian nurse, he lies in the Villa san Girolamo, a bombed out ruin in the hills north of Florence, a structure that once housed a nunnery and then the Germans. They mined the place when they left, only to have it taken over by the Allies as a hospital and morgue. By the time the novel opens, the only patient left is a man who has forgotten his name, and lost his history. His body, iconic in early passages of the body of Christ, reveals nothing in its charred flesh. His sense of self is anchored only in the fragmentary narratives of his life in the desert and his marginal notes and diary entries inscribed on the margins and in the added pages of his one possession, a battered copy of The Histories by Herodotus. His stories fill the villa during the days just after the cessation of war in Europe, his life the vehicle for Ondaatje's extraordinary elegy on the decline and fall of Western civilization.

If Herodotus and Florence together signify the best of the West, the great moments of Western self-invention and achievement, the rise of history and art, the triumph of beauty and reason, the English patient is the ideal subject of the Enlightenment. $\mathrm{He}$ is also the exemplar of colonial knowledge and the epitome of colonial adventure. An expert on the desert, he knows the Bedouin, as only colonial agents could: "I am a man who can recognize an unnamed town by its skeletal shape on a map...So I knew their place before I crashed among them, knew when Alexander had traversed it in an earlier age for this cause or that greed. I knew the customs of nomads besotted by silk or wells... When I was lost among them, unsure of where I was, all I needed was the name of a small ridge, a local custom, a cell of this historical animal, and the map of the world would slide into place $(18,19)$."2 There was no uncertainty, no resistance, no self-doubt; the cartography of colonial knowledge was total and absolute, no fragment less than the sign of the whole.

1 I am grateful to Adela Pinch, Marilyn Ivy, Janaki Bakhle, Peter van der Veer, and Val Daniel for extensive conversations about an earlier draft of this essay.

2 All page numbers come from the Vintage International Edition, New York, 1993. 
Colonial knowledge was also, so the claim went, disinterested. The English patient went to the desert, with other English friends, because of his love of untamed spaces: "We seemed to be interested only in things that could not be bought or sold, of no interest to the outside world (143)." But if knowledge was pure, if only in its originary enlightenment conceit, it was soon overtaken by war and the imperatives of nation states. Madox, the patient's best friend through ten years of desert exploration, could not bear the onset of war, the way it divided him from his small circle of friends, the noise it brought to his quiet fantasy of the desert: "And Madox returned to the village of Marston Magna, Somerset, where he had been born, and a month later sat in the congregation of a church, heard the sermon in honour of the war, pulled out his revolver and shot himself.. Yes, Madox was a man who died because of nations $(240,242)$." Clifton, who had joined the desert party on a lark after Oxford and marriage, turned out to be an intelligence officer for the British, his accumulated knowledge of the desert an added advantage once war was declared. And the English patient, well, he wasn't really English, after all. His story, first told in fragments that gave nothing away, was finally extracted during a long session of morphine, administered by Caravaggio the thief, who had used his skills for the counter-intelligence efforts of the British, and then, in the aftermath of war, followed his old family friend Hana, the nurse, to the villa. The English patient was in fact Hungarian, and had turned to help the Germans after the onset of war, guiding spies such as Rommel across the great North African desert. Caravaggio, with a thief's expertise in disguise, deduced his identity from the stories he first heard, having followed Almasy's case when he was posted in Cairo. But he could not have guessed the contingence of Almasy's betrayal.

Ondaatje's novel, at first seemingly seduced by the omniscience of colonial knowledge, traces its inexorable progression to the nuclear explosions over Hiroshima and Nagasaki. In the end, the novel - and this is where the true difference lies between fiction and history - is a romantic tale, writ small. Almasy had fallen in love with Clifton's wife when she seductively recited lines from Herodotus by desert campfire. It was an ancient story of betrayal, first by a husband of his wife, and then in return of a wife who conspires with the man her husband had chosen to see her naked in order to appreciate the beauty of his wife. As Almasy said when he narrated this story of falling in love: "Words, Caravaggio. They have a power (234)." History turned into romance through the seduction of language. But desire folds back into history when the story continues, for Almasy chose to side with the Germans only because the English suspected him, refusing to help him when he crawls into a military camp from a ruined desert crying out for them to rescue Katherine, whom he names, wrongly, as his wife. Though her husband is now dead, victim of a suicide crash that sought to take his wife and her lover to the next world with him, Almasy is unable to speak the husband's name, a name resonant with English upper class credential and military significance. And so he cannot save the woman he adores, and in retreat joins the enemy. Madox and Clifton die from broken hearts, Katherine from the misrecognition of war, and Almasy fades away (his colonial knowledge of the desert the means of his escape), only to be burned black, beyond recognition. When Almasy finally tells his tale, he has moved beyond desire, for either morphine or memory. Strangely, without memory all he can do is read the history of Herodotus. And he comes to his end, for his death is just a matter of time, a romantic who could not accept the 
inevitable appropriation of his knowledge and life: "We die containing a richness of lovers and tribes, tastes we have swallowed, bodies we have plunged into and swum up as if rivers we have hidden in as if caves. I wish for all this to be marked on my body when I am dead. I believe in such cartography - to be marked by nature, not just to label ourselves on a map like the names of rich men and women on buildings. We are communal histories, communal books. We are not owned or monogamous in our taste and experience. All I desired was to walk upon such an earth that had no maps."

He was, in the end, misguided. The condition of possibility of such romance was the colonial map that led directly to world war after world war, not to mention the daily oppressions of colonial rule. And in the final scene in the villa, the English patient has a gun directed at him by the Sikh sapper who had also taken refuge in the villa, a loyal soldier who had spent the war defusing unexploded bombs. He held his gun on the English patient after hearing about the explosion of the atomic bomb, a bomb he could never defuse. Holding the charred throat in the rifle's sight, he says: "My brother told me. Never turn your back on Europe. The deal makers. The contract makers. The map drawers. Never trust Europeans, he said. Never shake hands with them. But we, oh, we were easily impressed-by speeches and medals and your ceremonies. What have I been doing these last few years? Cutting away, defusing, limbs of evil. For what? For this to happen (284-85)." And when Caravaggio shouted out that the English patient was not English, it did not matter at all, though the sapper left him unharmed, returning home instead, though with his own troubling memories of Hana, his lover, to disturb the simple pleasures of his own national awakening.

The Florentine villa is still a ruin. The majestic mansion built by culture was hollowed out by the middle of the century, destroyed from within by the convulsions of world war, dismantled from without by the relentless historical logic of decolonization. Until the war it was possible for many to still believe the truth of Mathew Amold's pronouncements on the relationship of culture and anarchy. For Arnold, culture was not just the irrelevant preoccupation of the pedant, of interest only to "a critic of new books or a professor of belles lettres." Neither was culture of concern only to the upper classes. Culture was about the pursuit of perfection, about the contemplation of and devotion to sweetness and light: "It seeks to do away with classes; to make the best that has been thought and known in the world current everywhere; to make all men live in an atmosphere of sweetness and light, where they may use ideas, as it uses them itself, freely." Culture was thus, for Arnold, a "social idea:" "the men of culture are the true apostles of equality. The great men of culture are those who have had a passion for diffusing, for making prevail, for carrying from one end of society to the other, the best of knowledge, the best ideas of their time." These men of culture must strip the discourse of culture of all jargon and cant, humanizing and diffusing the benefits of culture for all. But the more Amold argues, the more it becomes clear how limited his notion of equality is: the masses should have culture disseminated to them by the "men" of culture in order to stem the inherent anarchy of the crowd. Culture, which is both animated by religious

\footnotetext{
${ }^{3}$ Mathew Arnold, Culture and Anarchy, Cambridge University Press, 1990, p. 68.

4 p. 70.

s. 70.
} 
impulses and the modern substitute for religion, "is the most resolute enemy of anarchy." And culture combats anarchy not just through its celebration of the sublime, but because it teaches us to nourish "great hopes and designs for the State." If culture is religion, the state is the new citadel of the sacred: "Thus, in our eyes, the very framework and exterior order of the State, whoever may administer the State, is sacred." And so the State and culture conspire to check the unruly and uplitt the public, to forbid both "despondency and violence."

Culture in Amold's Victorian view of the world has thus not only been tamed, but harnessed to the task of state control in the face of growing concern over the unruly mobs that threatened the pretensions and peace of a democratizing and secularizing England. ${ }^{9}$ Amold makes explicit the disciplining function of cultural value and the cultural elite; it is of little surprise that Amoldian phrases crop up time after time in the rhetoric of the conservative right in America (and Britain) today; William Bennett and Lynn Cheney both quoted Amold in their recent attacks on the National Endowments for Art and Humanities, giving voice to the concerns of many on the right that culture is supposed to combat anarchy rather than promote it. But Arnold's gloss of culture - the best that has been thought and known - as "sweetness and light" in the service of the state and the "men of culture" seems not only to provide a target for the most reductionist materialist critique of the superstructure but to parody even the most benign celebrations of culture emerging out of enlightenment discourse itself. Edmund Burke, whose writings on the sublime were of critical importance in the foundation of enlightenment aesthetics, realized that the power of culture was more complicated; Burke privileged darkness over light, secrecy over clarity. He also saw terror as the true source of the sublime: "Whatever is fitted in any sort to excite the ideas of pain, and danger, that is to say, whatever is in any sort terrible, or is conversant about terrible objects, or operates in a manner analogous to terror, is a source of the sublime; that is, it is productive of the strongest emotion which the mind is capable of feeling."10 For Burke, the sublime has much more to do with pain than with pleasure.

The sublime for Burke is not just about pain and terror, but, anticipating Kant, about the incommensurability of experience, at least some kinds of experience, and reason. As Sara Suleri has written: "Burke's famous catalog of the horrors of sublimity is thus strongly linked to a sense of temporal disarray, to a conviction that sequential derangement must necessarily attend the spectator's implication in the sublime. If a discourse of difficulty is the only idiom that will suffice to represent such derangement, then it demands to be recognized as clarity on its own territory, and resists a translation into aesthetic luminosity." Suleri stresses the performative entailments of the sublime, the implication of any reading of the sublime in the yawning chasm between representation

\footnotetext{
6 p. 204.

7 p. 204.

8 p. 204.

9 For a social history of the uses of culture in nineteenth century Britain, see Tony Bennett, "The Exhibitionary Complex," in Dirks, Eley, Ortner, eds, Culture/Power/History: A Reader in Contemporary Social Theory, Princeton University Press, 1994, pp. 123-154.

${ }^{10}$ Edmund Burke, A Philosophical Enquiry into the Origin of our Ideas of the Sublime and Beautiful, Oxford University Press, 1990, p. 36.

"Sara Suleri, The Rhetoric of English India, University of Chicago Press, 1992, p. 39.
} 
and event. The artifice of art calls attention to this gap; the power of representation is a conceit, predicated on the ultimate powerlessness of all representation. But the sublime is equally invested in the excess of all that is signified, the horrible truth that both representation and affect fall so far short of that which we seek to apprehend and understand. Culture in this view is not simple sweetness and light; art does not necessarily contain chaos, except perhaps in the picturesque cult of representation that took the sublime as the banal object of desire.

In picturesque conventions, the ruin was a sign of loss, of absence. Crumbling rock and fragments of shard stood for wholes that could never again be achieved, if even conceived. Ruins were approachable and representable, but only because they were but shadows of their former selves. Ruins made ancient truth both literal and literary. In ruins, the hollowed out shells of ancient truth appeared majestic, approachable only through art, painting and poetry in particular. The science of archaeology was born in the attempt to recover the truth of the past concretely, but the allure of archaeology was always predicated on the impossibility of scientific fantasy (not to mention its inescapable relationship to plunder, and the fantasy of instant wealth). Ruins also promised glory through recuperation rather than revolution, representing Burke's concern about the politics of the age, as well as about the relationship between history and the sublime. Perhaps more than anything, ruins made palpable the chasm between reality and representation, between desire and dejection, between now and then, lodging temporal alterity resolutely within the past rather than in some utopian future. The ruin not only housed culture, it stood for it: like culture itself, the ruin was at once material and ethereal, simultaneously about history and memory, a sign of achievement and a signal of failure, an inspiration for life as well as an intimation of death.

If culture's cavernous lack is the site of culture's power as well as the basis on which culture can be wielded as an instrument of power, the ruin helps us understand why culture must always be linked to the incommensurable. In Amold, culture becomes both didactic and inspiring, containable but dangerous. For Burke, the danger is more palpable; the power of culture is in part its excess, the uncontainability of the sublime. And for the picturesque tradition, that sought to contain beauty by conventions of distantiation, the experience was always on the verge of leaking beyond the borders of carefully composed canvases and gardens. Representation turned out to be as uncontrollable as the referential affects of romantic aspiration. The modern career of culture has always had to negotiate these tensions, requiring the convictions and investments of class power to sustain any confidence in the controlled and controlling uses of culture. But it is precisely these tensions - the quarrels over the empty spaces between representation and reality - that produce the terrific for Kant, the terrible for Burke, and the horrible for Benjamin. No matter where we rest our critical position, we find that culture is not quite itself, not nearly as comfortable as Amold would have us believe. For us all, culture is a site of extreme ambivalence, whether we refer to the ruin in the garden, the nude in the museum, or the harmony in a chorale. Now we attempt to clothe ambivalence in a different kind of distance, and we shift from the effort to describe and contain the sublime to a critical consideration of the political implications of the power of culture. But we are still drawn to culture as if it is a spectre, the ghost of a past that still excites and the haunting possibility of a future we think we desire. Culture eclipses temporality itself even as we 
try to historicize it. Culture becomes a trace of its own representational artifacts, that can be critiqued only when we are still compelled by the terrible pull of the sublime. As the impossible object of our critical conscience, culture either floats away into thin air as absence, or takes the form and presence of the ruin.

In the Midraash story of the Tower of Babel, those who actually saw the ruins of the tower were doomed to forget the past, to lose sight of history altogether, to forfeit even their capacity to know themselves. ${ }^{12}$ While ruins would seem to be about history, more often they are about the need to obliterate history, as well as signs of the death of history. Walter Benjamin distinguishes historical materialism from the history of Fustel de Coulanges, who "recommends...to historians who wish to relive an era...that they blot out everything they know about the later course of history." 13 Benjamin goes on to write, in his now famous passage, that "without exception the cultural treasures he [the historical materialist] surveys have an origin which he cannot contemplate without horror. They owe their existence not only to the efforts of the great minds and talents who have created them, but also to the anonymous toil of their contemporaries. ${ }^{14}$ The ruin is the document of civilization par excellence; it signifies the most onerous toil of the slaves and subalterns who executed the political and architectural ambitions of great civilizations, and the history of its contemplation generates nostalgia which is the forgetting rather than the remembering of history, the forgetting of the conditions of possibility of history, not to mention its later course. But for those, unlike Benjamin, who have traditionally celebrated culture, and civilization, the only horror attendant upon the contemplation of ruins is that of shock at the decline and fall of what once was great. The ruin is the only connection between the wonders of the past and the degradation of the present. The ruin puts us in awe of the mystifications that made civilization magnificent in the first place. The ruin is culture, both its reality and its representation.

If Benjamin teaches us more powerfully than perhaps any other modern critic that culture is a ruin, he betrays some measure of his own nostalgia when he defines the aura of traditional aesthetics. In Benjamin's early philosophy he had identified the aura, or uniqueness, or art as the source of its value; by the time he wrote his masterful essay, "Art in the Age of Mechanical Reproduction," he had reversed his view. ${ }^{15}$ Whether produced by "cult value" (the ritual attribution of magical value) or by the logic of exhibition (the public presentation of works of art) Benjamin now views the aura of art, that quality of authenticity and presence that produces the sublime, as an endangered species. Art changes fundamentally once the technical means of reproduction enter the modern world with photography in the nineteenth century. In a flashback to his earlier position, the moment when the aura appears lost produces a "melancholy, incomparable beauty." 16 Nevertheless, Benjamin argues strongly that the loss of the aura opens up new possibilities

12 "The ruins of the Tower can be seen to this day. But he who sees them is cursed with the loss of memory. All the people on earth who go around saying, "Who am I, Who am I," are ones who have seen the ruins of the Tower of Babel." Midrash Rabbah. I am grateful to Anton Shammas for bringing this to my attention.

${ }^{13}$ Walter Benjamin, Illuminations, Fontana Collins, 1982, p. 258.

14 p. 258.

15 Susan Buck-Morss, The Origin of Negative Dialectics: Theodor W. Adorno, Walter Benjamin, and the Frankfurt Institute, Free Press, p. 147.

${ }^{16}$ Benjamin, p. 228. 
for a revolutionary aesthetic, for the politicization and radicalization of art. Film is exemplary of the new aesthetic regime: film, according to Benjamin, promotes a "revolutionary criticism of traditional concepts of art." 17 By its substitution of the camera for the public, film loses the aura of performance; by its reproducability and accessibility, it makes every viewer an expert. Film embodies the principal of the mechanical reproduction of art, thus irrevocably changing "the reaction of the masses toward art." Benjamin had extraordinary confidence in the progressive implications of the new age of film.

But Benjamin's faith in the technologies of aesthetic reproduction and the critical capabilities of the masses (politically self-conscious if also absent minded) was strenuously opposed by Adorno, who was far more distrustful of the "laughter of the proletariat in the movie house," ${ }^{18}$ and far more impressed by the capacities of the fascist state and the capitalist elite to appropriate the technologies of production. The argument between Benjamin and Adorno over popular and elite culture continues to haunt our understandings of culture in the final years of the twentieth century. Now the question is not whether culture, or the sublime, can be contained, so much as whether the modern technologies of the sublime will render containment that much more secure. Adorno's critique of the culture industry, ${ }^{19}$ composed in its most complete and polemical form after his move to America, still provides the most eloquent critique of mass culture we have today. Adomo lamented that "real life is becoming indistinguishable from the movies."20 He argued that "the stunting of the mass-media consumer's powers of imagination and spontaneity does not have to be traced back to any psychological mechanisms; he must ascribe the loss of those attributes to the objective nature of the products themselves, especially to the most characteristic of them, the sound film."21 Adorno wrote more generally that "The culture industry as a whole has molded men as a type unfailingly reproduced in every product."22 Anticipating current theoretical preoccupations with cultural hegemony and discursive domination, Adomo carefully dissected the ways in which the modern subject was converted into a consumer, a consumer whose needs, interests, and beliefs could be controlled and manipulated by the apparatusses of a mass media that produced pleasure (and incited further consumption) by stifling the possibility of critical reflection. With polemical rhetoric still unrivalled by other denunciations of the conceits of bourgeois liberalism, Adomo noted at the end of his essay that the methods of the fascists had reached their final apotheosis in modern America, where the "freedom to choose an ideology...everywhere proves to be freedom to choose what is always the same." 23

Using Benjaminian language, if to rather different ends, Adorno wrote that "Today aesthetic barbarity completes what has threatened the creations of the spirit since they

\footnotetext{
17 Benjamin, p. 233.

18 Buck-Morss, p. 149.

19 published in Horkheimer and Adomo, Dialectic of Enlightenment, New York: Herder and Herder, 1972 (1947).

${ }^{20}$ p. 126.

21 p. 126.

22 p. 127.

${ }^{23}$ pp. $166,167$.
} 
were gathered together as culture and neutralized. ${ }^{224}$ The culture industry has rendered culture nothing but style, in which the commodification of all aesthetic value reveals itself in the reduction of art to imitation. Adorno held up older and more classical forms of culture in contrast, noting that "the great artists were never those who embodied a wholly flawless and perfect style, but those who used style as a way of hardening themselves against the chaotic expression of suffering, as a negative truth."25 While recognizing that art is always ideology, Adorno saw the confrontation with tradition in classical forms as the contradictory space for the expression of suffering, and for the necessary admission of failure through self-negation, the contradictions of any effort to transcend the particular limits of social existence. In this short aside, Adorno made reference to a life-time of critical efforts to engage in ideology critique through great works of art, in particular the modernist musical experiments of composers such as Schonberg.

Adorno's commitment to the critical potential of high modernist aesthetics, and his despair about mass culture, was a function of his experience of the normalization and appropriation of a classical tradition under the Nazi regime, as well as of the apparent utility of mass culture for totalitarian state systems and American capitalist market forces alike. Benjamin's belief in the potential of mass media was forged through his fascination with early film, as also his political and cultural affiliation with Brecht. Benjamin was convinced that the loss of aura represented by filmic media. would render culture both more accessible and more political, but even if his commitment to Marxist doctrine and revolutionary praxis was far firmer than that of Adorno, it seems likely he would have worried along with Adorno about the production of new consumer subjectivities under the postwar American regime of capital, had he survived the war. The war itself, despite Adorno, left traditional European culture as a ruin, both architecturally - many of its most conspicuous symbols were literally ruined - and spiritually; it was clear to many that the heart of European culture had in some ways led to fascism and the holocaust. Ideology critique seemed woefully insufficient. At the same time, the ruins of Europe paved the way for the emergence of American hegemony over world culture, ruining cultural sensibility/possibility in precisely the terms laid out so eloquently by Adorno. Culture under the new regime became always already a ruin in the face of programmed obsolescence and the relentless advance of the new. After the war, culture was taken over by Eisenhower's military industrial complex and Hollywood's fantasy factories. And the cold war deployment of modernization, appropriating all the other uses of the modern to the world order of American power, affiliated the new with economic power, technological superiority, progress and pleasure. The lure of the modern was more powerful than ever, and once again, the modern came as a sign of Western power.

And so we return to the Villa san Girolamo. The Florentine shrine of culture was a ruin, its inhabitants shell shocked. The image recapitulates the modernist critique of the sublime, forcefully set in motion by Nietzsche when, arguing that both the Apollonian and the Dionysian principles were conjoined in aesthetic production and experience, he took the Kantian tradition to task for failing to recognize that "the sublime is the artistic taming

${ }^{24}$ p. 131.

25 p. 130. 
of the horrible. ${ }^{26}$ Nietzsche's insistence on the Dionysian side of the sublime anticipated the later writings of George Bataille, who viewed cultural value and meaning as necessarily implicated in violence and excess. Focussing on rites of sacrifice and the close relations between ritual and war, Bataille interrogated the horror at the heart of culture, celebrating transgression as the fundamental modality of the sacred. For Bataille, as for Nietzsche, the moment of excess was both about sexuality and about death. ${ }^{27}$ And even here, surveying the theoretical genealogies of our current condition, Ondaatje captures this sad sense of the sullied sublime. We see in his novel the necessary affiliation of love and violence; Almasy's love is obiterated by war, even as Hana and the Sikh sapper are torn apart by the nuclear explosion thousands of miles away. ${ }^{28}$ Violence is what predicates love (in the colonial terrain of the desert, or in the ruined villa), and violence is the force that ultimately disrupts it.

In the end, the English patient, the man who used Herodotus as his guide through the deserts of life, lay waiting for death, burned black beyond identity. He was a man who embodied the "best" of colonial knowledge and yet now lay lost in the annals of a classical knowledge that seemed quaint and academic. And, too, he turned out to be not quite what he seemed; he belonged to all of Europe, erasing the distinctions between allies and axis by revealing the common heritage and fundamental flaws of both sides. The pathos of his life provided the pretext for the ultimate intendment of the novel, the devolution of cultural capital from Almasy and his Oxford education to the likes of Caravaggio and Hana, the one a streetwise though chastened thief, the other a young and beautiful woman who had already seen the empty deception of the domestic dream. And even more significantly, the position of critique is appropriated in the end by the silent sapper, the Sikh from India who recognizes the ultimate deception, the terrible tyranny of the West, the translation of European colonial power into American English. The ruin that haunts the final pages of the novel is that of Hiroshima and Nagasaki, cities instantaneously converted to rubble by the unprecedented power of nuclear explosion. When the sapper returns home, he does so to join in the final struggle of the nationalist movement, to attempt to free himself, for good, of the ruination of the West.

In these remarks, I have sought to capture, or at least evoke, the predicament of cultural theory today, fifty years after the end of the war, during these intervening years, American power has waxed and waned, popular culture has exploded across the globe, decolonization has transformed the cartography of colonial power, and the death of communism has led to the demise of the cold war and the epiphany of market capitalism. Ondaatje wrote his allegory from the perspective of these transformations; in an earlier novel set in Toronto he had written about the historical production of subjects such as Caravaggio and Hana (In the Skin of a Lion), and in a personal memoir, he had evoked the lush colonial past that had generated his own mediated relationship with his home, Sri Lanka (Running in the Family). In particular, Ondaatje tells his tale from the position of one who celebrates an escape from the West at the same time he is irrevocably trapped in its embrace. Decidedly not a postcolonial theorist, Ondaatje has reflected deeply on the

\footnotetext{
${ }^{26}$ Friedrich Nietzsche, The Birth of Tragedy, New York, Vintage Books, 1964, p. 60. I am grateful to Peter van der Veer for pointing this passage out to me.

27 See Georges Bataille, The Accursed Share, New York: Zone Books, 1991.

28 Again, I am grateful to Peter van der Veer for forcing me to bring out this parallel more clearly.
} 
entailments of the history and genealogy of the West for cultural migrants such as himself, he has immersed himself in the poetic possibilities of a colonial language at the same time he dreams of the authentic heat and passion of his youth; he has identified the hybrid formations that relentlessly enclose his own capacity for history and utopia. Without any explicit reference to Adorno, he exemplifies Adorno's own reflection about the dislocations of his life and times: "For a man who no longer has a homeland, writing becomes a place to live." 29

Writing may provide a sense of home, but it is decidedly not a neutral space. In the last fifty years we have learned how much it matters from where we write, to whom we write, and more generally how writing is positioned in geo-political, socio-historical, and institutional terms. If Ondaatje's English Patient can signify the monumental shifts in our cultural and intellectual landscape that have been brought about by decolonization and resurgent nationalism, it can also remind us that in cultural theory, postcolonial critiques are necessary features of all the new landscapes we inhabit, or survey. Postcoloniality, in other words, is not just something out there, neither is it (nor should it be) simply a new name for a token inclusionism in our cultural business as usual. Rather, the postcolonial condition is the historical precipitate of centuries of western political and economic domination, itself enabling, even as it was enabled by, centuries of cultural and intellectual colonization. Postcoloniality signifies those places and peoples that resist the universalization of positionality and perspective, even as it underscores the extraordinary power of the forces of universalization. Postcoloniality reminds us of the fact that culture and modernity were always flawed, always predicated on violence and domination even as they were the terms of seduction and conquest for colonization itself. ${ }^{30}$ When the critique of the enlightenment comes out of colonial history, we remember that Burke's eloquent defence of good government and disinterested despotism was in the service of massive force, monumental greed, unsupportable grandeur. We remember that culture has always been a spectre, haunting any attempt to reconstruct cultural authenticities untouched by colonial power even as it leaves a trace of violence in every moment of historical imagination and political utopia. The angel of history speaks with sadness not just about the atrocities of the past, but the atrocity of history itself, propelled as he is into the future by the terrible storm called progress. ${ }^{31}$

The cultural field at the end of the twentieth century, from wherever we stand, is made of fragments. If traditional culture is still a (near) ruin, and much of popular culture still a (near) ruination, we have neither resolved the argument between Benjamin and Adorno, nor fixed upon new ways to engage the field of culture that escape the problematic legacies of class hegemony, colonial domination, and capitalist exploitation. We are still uncertain about our place as intellectuals, and wherever we position ourselves

29 Buck-Morss, p. 190.

30 I refer here, of course, to the field that has been established in the wake of Edward Said's Orientalism, New York, Vintage Books, 1979; for Said's most recent treatment of the relation of imperialism to western cultural legacies, see his, Culture and Imperialism New York: Knopf, 1993.

${ }^{31}$ Benjamin writes, "The angel would like to stay, awaken the dead, and make whole what has been smashed. But a storm is blowing from paradise; it has got caught in his wings with such violence that the angel can no longer close them. This storm irresistably propels him into the future to which his back is turned, while the pile of debris before him grows skyward. This storm is what we call progress."

Illuminations, pp. 259-260. 
we are not completely sure what these places signify in relation to concerns of constituency and representation, let alone the politics of criticism. The argument between Benjamin and Adomo continues to haunt us; we are not sure whether to find resistance in culture (whether "low" or "high"), to attempt to provoke subversion in culture through ideology critique, or to feel embarassment about the choice of culture as the field of criticism and interpretation in the first place.

But we keep coming back to the ruins of culture. We may feel horrified, but we also feel inspired; we may feel dispirited, as did Adorno, but we cannot escape the rhetorical echoes of Benjamin's utopian aspiration. When we confront the overdetermination of logics of cultural production and consumption, we may nowadays think more of Foucault than of Marx; when we experience the excess of cultural meaning and signification, we may refer more to Bataille than to Burke. But we keep coming back. We stroll across the delapidated ramparts, we climb the devastated staircase, we sift through the sandy pieces of shard, we back up on a grassy knoll until we can see the grandeur and the beauty of the prospect. But there we are, and we cannot just stand back, despite the fact, perhaps because of the fact, that we now know the ruin is littered with unexploded mines. When we walk in the library we know, as did Hana, that one wrong step may detonate the fuse of a deadly bomb. We pull books down from shelves knowing not what we may find, nor how old books might read again, now after the war. We plant flowers in the garden, never sure if the weeds we pull, or the sharp blade of our trowel, will trigger an explosion. We exist in a state of emergency; we live in near ruins. 
NOTES : 